\title{
Effect of Emulsifier in Low Energy Ration Containing Rice bran oil on Growth Performance of Broiler Chickens
}

\author{
G. Srinivasan*, N. Arul Nathan, V. Thanaseelaan, A. Ruba Nanthini and Sunil Chauhan
}

Tamil Nadu Veterinary and Animal Sciences University, Chennai- 600 051, India

*Corresponding author

\section{Keywords}

Broilers, Crude rice bran oil, Emulsifier, Lipase, Growth performance

\section{Article Info}

Accepted:

18 May 2020

Available Online:

10 June 2020

\section{A B S T R A C T}

Growth study was conducted to study the effect of emulsifier in low energy diets containing rice bran oil as fat source in the growth performance of commercial broiler chicken. Three treatment groups were fed with basal diet contains crude rice bran oil as energy source $\left(T_{1}\right)$, basal diet supplemented with emulsifier at the rate of $250 \mathrm{~g}$ per MT of feed $\left(\mathrm{T}_{2}\right)$ and $80 \mathrm{kcal}$ Metabolizable energy reduced from basal diet supplemented with emulsifier at the rate of $250 \mathrm{~g}$ per MT of feed $\left(\mathrm{T}_{3}\right)$. Significantly higher cumulative body weight was noticed in $\mathrm{T}_{3}$ group $(2605 \mathrm{~g})$ which was comparable with $\mathrm{T}_{2}(2569 \mathrm{~g})$ and differs significantly with $\mathrm{T}_{1}(2422 \mathrm{~g})$ at $6^{\text {th }}$ week of age. Improved cumulative feed conversion ratio was obtained in $T_{3}$ (1.76) and $T_{2}$ (1.76) groups and differed significantly with $T_{1}(1.89)$ group at $6^{\text {th }}$ week of age, Slaughter studies revealed comparable dressing percentages between $\mathrm{T}_{2}(68.43 \%)$ and $\mathrm{T}_{3}(67.34 \%)$ and significantly lower dressing percentage in $\mathrm{T}_{1}(66.94 \%)$. No significant difference noticed between treatments in carcass parameters and serum biochemical parameters. Inclusion of emulsifier in the low energy broiler ration containing crude rice bran oil has improved cumulative body weight and cumulative feed conversion ratio at market age of broiler chicken.

\section{Introduction}

India is the fourth largest chicken producer in the world with annual production of 3.8 million tonnes of broiler meat. The broiler industry has been changed a lot in recent decades. With continuous genetic improvement and nutritional modification the body weight gain and feed conversion ratio of broilers drastically improved. Dietary energy is the important component which increases weight gain and improves feed conversion ratio (Bell, 2007). Mostly in broiler feeds oil is used as concentrate source of energy. Fat digestion is mainly done by lipase. Fat provides twice the energy than either carbohydrates or protein source. Oils increase the feed intake by its flavour and improve the absorption of fat soluble vitamins in the gut.

Digestion of fat mainly done by lipase enzyme, which cannot work until fat is emulsified. In broilers, emulsification mainly done by bile salts, but most of the time its production is not sufficient to emulsify the fat and oil added to the diet. 
Hence, Addition of emulsifiers to broiler diet is a recent practice to improve utilization of fat source. (Roy et al., 2010) which increase the active surface of fats allowing more action of lipase to hydrolyse the fats and increases absorption. Emulsifiers can be used to improve fat digestibility and improve energy efficiency (Maertens et al., 2015). As a result, broiler ration can be formulated with low energy diet to maintain the same performance, lower feed cost and economical production. The rice bran is a promising vegetable oil widely used in broiler feed as energy source. Hence, this study was undertaken to study the effect of emulsifier in low energy ration containing rice bran oil on growth performance in broilers.

\section{Materials and Methods}

A total of 90 day old Vencobb- 320 broiler chicks belonging to single hatch were procured from local hatchery, wing banded, weighed and randomly distributed into three treatments at the rate of 30 birds per treatment with 5 chicks per replicate using completely randomized design. All the chicks were reared under standard managemental conditions under deep litter system of rearing with ad libitum provision of feed and water throughout the experimental period. The fat emulsifier used in this experiment was purchased from Jubliant Life Sciences, Noida. Crude rice bran oil was uses as fat source in all the treatments. The Iso nitrogenous experimental diets were prepared (Table 1) as per Bureau of Indian Standards (BIS, 2007). The chicks were offered with basal diet, basal diet supplemented with fat emulsifier at the rate of $250 \mathrm{~g}$ per MT of feed and $80 \mathrm{kcal}$ energy reduced from basal diet supplemented with emulsifier at the rate of $250 \mathrm{~g}$ per MT of feed in treatments $T_{1}, T_{2}$ and $T_{3}$ respectively. Cumulative body weight and, cumulative feed consumption were recorded weekly. Blood samples were collected at the end of the experiment from wing vein of birds in sterile tube and used to study the serum biochemical profile like uric acid $(\mathrm{mg} / \mathrm{dl})$, creatinine $(\mathrm{mg} / \mathrm{dl})$, total Protein $(\mathrm{g} / \mathrm{dl})$, albumin $(\mathrm{g} / \mathrm{dl})$, globulin (mg/L), ALT (IU/L), AST (IU/L), triglycerides $(\mathrm{mg} / \mathrm{dl})$, total cholesterol (mg/dl), HDL Cholestrol (mg/dl) and Glucose $(\mathrm{mg} / \mathrm{dl})$ were estimated. At the end of experiment, three birds from each replicate were selected randomly and slaughtered ethically to study the dressing yield, breast meat, drumstick meat yield and abdomen fat percentage. Data were analysed using completely randomized design the procedures of Snedecor and Cochran (1989) using statistical analysis system (IBM SPSS Version 20.0).

\section{Results and Discussion}

\section{Growth performance}

The data on cumulative body weight was given in Table 2. There was significant difference $(\mathrm{P}<0.05)$ in cumulative body weight between treatment groups in all weeks of age. The emulsifier supplementation significantly increased body weight in all the weeks of trial period. Emulsifier added with energy reduced treatment group $\left(\mathrm{T}_{3}\right)$ shown significantly higher body weight (182.6g, $448.7 \mathrm{~g}, 857 \mathrm{~g}, 1313.2 \mathrm{~g}, 1927.2 \mathrm{~g}$ and $2652 \mathrm{~g})$ than basal diet $\left(\mathrm{T}_{1}\right)$ treatment group $(162.7 \mathrm{~g}$, $427.9 \mathrm{~g}, 787.8 \mathrm{~g}, 1219.9 \mathrm{~g}, 1759.8 \mathrm{~g}$ and $2468 \mathrm{~g}$ ) from first to sixth week of age. Except first and fifth weeks of age body weight of $\mathrm{T}_{3}$ was comparable with Emulsifier added group $\left(\mathrm{T}_{2}\right)$.

At $6^{\text {th }}$ week of age highest body weight was recorded in $\mathrm{T}_{3}$ group (2652g) followed by $\mathrm{T}_{2}$ $(2617 \mathrm{~g})$ and $\mathrm{T}_{1}(2468 \mathrm{~g})$ group. Results of this experiment agreed with An et al., (2020) who found that at the end of the experiment, the final body weight of the broilers was significantly higher $(p<0.05)$ in broilers fed the diet supplemented with $0.2 \%$ exogenous 
emulsifier than in the other treatment groups. Findings of Bontempo et al., (2018) showed a significant improvement in average daily gain with the supplementation of synthetic emulsifier to the feed for one to 12 days. However, the results of the study disagreed with findings of Ferreira et al., (2005) who did not find any significant difference in production performance among birds fed with soya bean oil and tallow with emulsifier.

Similarly, Guerreiro Neto et al., (2011) did not find any difference in broiler growth performance on addition of emulsifier with fat source at 42 days of age. In a similar study, Dabbou et al., (2019) reported that there were no significant differences in Body weight gain or feed intake by supplementation with natural emulsifiers for one to 10 days.

\section{Cumulative feed intake}

The cumulative feed intake of birds fed with or without emulsifier is presented in Table 3 revealed no significant difference in feed intake noticed between treatment groups at $6^{\text {th }}$ week of age, but numerically lowered feed intake was observed in $\mathrm{T}_{3}$ and $\mathrm{T}_{2}$ groups.

Kulkarni, et al., (2019) reported that supplementing emulsifier in the diet prepared with different oil sources like soya bean oil and rice bran oil as fat source, the feed intake was comparable among different treatment groups during staring phase (0-3 week) but significant increase in feed intake was observed during finishing (3-6 weeks).

Aguilar et al., (2013) reported that supplementing emulsifier and increasing levels of energy provided by palm oil did not affect the feed intake in any period. However, the feed intake of broilers may vary depending on the size of the feed, which requires a more precise study of growth performance.

\section{Feed conversion ratio}

The data on cumulative FCR presented in Table 4. At $6^{\text {th }}$ week of age significant difference $(\mathrm{p}<0.05)$ in FCR was noticed between $T_{3}$ (1.76) and $T_{1}(1.89)$ group but comparable FCR was noticed between $\mathrm{T}_{2}$ and $\mathrm{T}_{3}$ groups. There was no significant difference noticed between $T_{2}$ and $T_{3}$ groups in all weeks of trial period, however, except first week numerically improved FCR was noticed in $\mathrm{T}_{3}$ group.

The improved feed conversion ratio may be due to effect of fat emulsifier which improves fat digestibility and energy utilization. Results of this experiment agreed with An et al., (2020) who reported that supplementing emulsifier at the rate of $0.1 \%$ and $0.2 \%$ in $\mathrm{T}_{1}$ and $\mathrm{T}_{2}$ treatment groups had significantly lower feed conversion ratios $(\mathrm{p}<0.05)$ than broilers in the control group. Guerreiro Neto et al., (2011) reported that improved FCR was noticed in broiler diet containing soya bean oil with emulsifier. Bontempo et al., (2018) who reported that FCR was lower when fed AMT emulsifier from $22^{\text {nd }}$ day to $44 \mathrm{t}^{\mathrm{h}}$ day.

The result of this experiment was also agreed with Roy et al., (2010) with exogenous emulsifiers reported beneficial effects on digestibility, body weight, FCR, weight gain and abdominal fat in broiler chicks. The improved FCR could be due to improved energy digestibility depending on the fat source in the normal diet.

\section{Carcass parameters}

The effects of supplementing emulsifier on carcass parameters were given in Table 5. The data revealed that there is no significant difference $(\mathrm{p}<0.05)$ was noticed in dressing percentage, breast meat yield and drumstick percentage and abdominal fat percentage among treatment groups. 
Table.1 Ingredients and chemical composition of broiler Pre starter, Starter and Finisher diets (\%)

\begin{tabular}{|c|c|c|c|c|c|c|c|c|c|}
\hline \multirow[t]{2}{*}{ Ingredients (kg/100kg) } & \multicolumn{3}{|c|}{ PBS } & \multicolumn{3}{|c|}{ BS } & \multicolumn{3}{|c|}{ BF } \\
\hline & $\mathrm{T}_{1}$ & $\mathrm{~T}_{2}$ & $\mathrm{~T}_{3}$ & $\mathrm{~T}_{1}$ & $\mathrm{~T}_{2}$ & $\mathrm{~T}_{3}$ & $\mathrm{~T}_{1}$ & $\mathrm{~T}_{2}$ & $\mathrm{~T}_{3}$ \\
\hline Maize & 49.80 & 49.80 & 52.8 & 50.20 & 50.20 & 52.76 & 61.19 & 61.19 & 63.27 \\
\hline Soya & 41.90 & 41.90 & 40.6 & 40.11 & 40.11 & 39.34 & 31.99 & 31.99 & 31.64 \\
\hline Salt & 0.30 & 0.30 & 0.30 & 0.30 & 0.30 & 0.30 & 0.31 & 0.31 & 0.31 \\
\hline Calcite & 1.20 & 1.20 & 1.29 & 0.97 & 0.97 & 0.98 & 1.44 & 1.44 & 1.44 \\
\hline DCP & 1.81 & 1.81 & 1.82 & 2.00 & 2.00 & 2.00 & 1.06 & 1.06 & 1.04 \\
\hline Crude rice bran oil & 3.79 & 3.79 & 2.0 & 5.50 & 5.50 & 3.70 & 3.02 & 3.02 & 1.34 \\
\hline Methionine & 0.32 & 0.32 & 0.30 & 0.22 & 0.22 & 0.20 & 0.17 & 0.17 & 0.16 \\
\hline Lysine & 0.22 & 0.22 & 0.21 & 0.07 & 0.07 & 0.05 & 0.10 & 0.10 & 0.08 \\
\hline Vitamin Premix* & 0.05 & 0.05 & 0.05 & 0.05 & 0.05 & 0.05 & 0.05 & 0.05 & 0.05 \\
\hline Mineral premix* & 0.2 & 0.2 & 0.2 & 0.2 & 0.2 & 0.2 & 0.2 & 61.19 & 0.2 \\
\hline \multicolumn{10}{|c|}{ Nutrient Composition ( Calculated) } \\
\hline CP (\%) & 23.0 & 23.0 & 23.0 & 22 & 22 & 22 & 20 & 20 & 20 \\
\hline Crude fibre (\%) & 3.51 & 3.51 & 3.48 & 3.37 & 3.39 & 3.42 & 3.17 & 3.15 & 3.16 \\
\hline Ether extract (\%) & 5.78 & 5.78 & 4.47 & 7.14 & 7.05 & 5.85 & 5.40 & 5.45 & 4.04 \\
\hline $\begin{array}{l}\text { Metabolizable energy } \\
\text { K.cal }\end{array}$ & 3000 & 3000 & 2920 & 3100 & 3100 & 3020 & 3200 & 3200 & 3120 \\
\hline
\end{tabular}

*supplies per kg of diet Vitamin A 16,500 IU, Vitamin $\mathrm{D}_{3} 3200 \mathrm{ICU}$, Vitamin E 12mg, Vitamin K 2 mg, Vitamin $\mathrm{B}_{2} 10$ $\mathrm{mg}$, Vitamin B6 2.4mg, Vitamin B12 $12 \mu \mathrm{g}$, Niacin 18mg, Pantothenic acid 12mg, Mn 90mg, Zn 72mg, Fe 60mg, Cu $10 \mathrm{mg}$, Iodine $1.2 \mathrm{mg}$

Table.2 Mean cumulative body weight ( $\mathrm{g}$ ) of broilers in various periods

\begin{tabular}{|c|c|c|c|}
\hline Age in weeks & Treatment 1 & Treatment 2 & Treatment 3 \\
\hline Hatch weight & $45.82^{\mathrm{Ns}} \pm 0.76$ & $47.82^{\mathrm{Ns}} \pm 0.48$ & $46.52^{\mathrm{Ns}} \pm 0.66$ \\
\hline $\mathbf{1}^{\text {st }}$ week & $162.68^{\mathrm{a}} \pm 1.26$ & $188.06^{\mathrm{b}} \pm 0.37$ & $182.58^{\mathrm{c}} \pm 1.82$ \\
\hline $\mathbf{2}^{\text {nd }}$ Week & $427.98^{\mathrm{a}} \pm 4.10$ & $452.94^{\mathrm{b}} \pm 1.25$ & $448.7^{\mathrm{b}} \pm 3.06$ \\
\hline $\mathbf{3}^{\text {rd }}$ Week & $787.78^{\mathrm{a}} \pm 17.06$ & $834.8^{\mathrm{ab}} \pm 11.88$ & $857^{\mathrm{b}} \pm 25.89$ \\
\hline $\mathbf{4}^{\text {th }}$ Week & $1219.9^{\mathrm{a}} \pm 22.39$ & $1261.2^{\mathrm{ab}} \pm 6.85$ & $1313.2^{\mathrm{b}} \pm 32.57$ \\
\hline $\mathbf{5}^{\text {th }}$ Week & $1759.8^{\mathrm{a}} \pm 32.90$ & $2034^{\mathrm{b}} \pm 34.73$ & $1927.2^{\mathrm{c}} \pm 16.69$ \\
\hline $\mathbf{6}^{\text {th }}$ Week & $2468^{\mathrm{a}} \pm 24.63$ & $2617^{\mathrm{b}} \pm 22.89$ & $2652^{\mathrm{b}} \pm 31.65$ \\
\hline
\end{tabular}

Mean value sharing any one common superscript in a column did not differ significantly $(\mathrm{p}<0.05)$

Table.3 Mean Cumulative feed intake (g) of broiler in various periods

\begin{tabular}{|c|c|c|c|}
\hline Age in weeks & Treatment 1 & Treatment 2 & Treatment 3 \\
\hline $\mathbf{1}^{\text {st }}$ week & $147.6^{\mathrm{Ns}} \pm 0.93$ & $149.4^{\mathrm{Ns}} \pm 2.93$ & $149.2^{\mathrm{Ns}} \pm 0.86$ \\
\hline $\mathbf{2}^{\text {nd }}$ Week & $493.46^{\mathrm{b}} \pm 4.95$ & $479.8^{\mathrm{a}} \pm 3.28$ & $469^{\mathrm{a}} \pm 3.30$ \\
\hline $\mathbf{3}^{\text {rd }}$ Week & $1034.91^{\mathrm{Ns}} \pm 18.82$ & $1032.396^{\mathrm{Ns}} \pm 9.42$ & $1032.62^{\mathrm{Ns}} \pm 9.33$ \\
\hline $\mathbf{4}^{\text {th }}$ Week & $1782.73^{\mathrm{Ns}} \pm 39.45$ & $1736.79^{\mathrm{Ns}} \pm 18.92$ & $1777.75^{\mathrm{Ns}} \pm 19.76$ \\
\hline $\mathbf{5}^{\text {th }}$ Week & $2794.2^{\mathrm{a}} \pm 67.72$ & $3115.79^{\mathrm{b}} \pm 54.66$ & $2882.25^{\mathrm{a}} \pm 28.26$ \\
\hline $\mathbf{6}^{\text {th }}$ Week & $4590.01^{\mathrm{Ns}} \pm 65.21$ & $4520.80^{\mathrm{Ns}} \pm 69.36$ & $4586.26^{\mathrm{Ns}} \pm 46.32$ \\
\hline
\end{tabular}

Mean valve sharing any one common superscript in a column did not differ significantly $(\mathrm{p}<0.05)$ 
Table.4 Mean Feed Conversion Ratio of broiler chicken in various periods

\begin{tabular}{|c|c|c|c|}
\hline & Treatment 1 & Treatment 2 & Treatment 3 \\
\hline $\mathbf{1}^{\text {st }}$ week & $1.263^{\mathrm{b}} \pm 0.02$ & $1.065^{\mathrm{a}} \pm 0.02$ & $1.097^{\mathrm{a}} \pm 0.02$ \\
\hline $\mathbf{2}^{\text {nd }}$ Week & $1.291^{\mathrm{b}} \pm 0.02$ & $1.184^{\mathrm{a}} \pm 0.01$ & $1.166^{\mathrm{a}} \pm 0.02$ \\
\hline $\mathbf{3}^{\text {rd }}$ Week & $1.39^{\mathrm{b}} \pm 0.04$ & $1.31^{\mathrm{ab}} \pm 0.02$ & $1.27^{\mathrm{a}} \pm 0.03$ \\
\hline $\mathbf{4}^{\text {th }}$ Week & $1.51^{\mathrm{b}} \pm 0.03$ & $1.4^{\mathrm{a}} \pm 0.02$ & $1.4^{\mathrm{a}} \pm 0.02$ \\
\hline $\mathbf{5}^{\text {th }}$ Week & $1.63^{\mathrm{b}} \pm 0.02$ & $1.57^{\mathrm{ab}} \pm 0.03$ & $1.53^{\mathrm{a}} \pm 0.01$ \\
\hline $\mathbf{6}^{\text {th }}$ Week & $1.89^{\mathrm{b}} \pm 0.04$ & $1.76^{\mathrm{a}} \pm 0.04$ & $1.76^{\mathrm{a}} \pm 0.01$ \\
\hline
\end{tabular}

Mean valve sharing any one common superscript in a column did not differ significantly $(\mathrm{p}<0.05)$

Table.5 Mean values of slaughter studies of broiler chicken (\%)

\begin{tabular}{|c|c|c|c|}
\hline Trait & Treatment 1 & Treatment 2 & Treatment 3 \\
\hline Dressing percentage & $66.94 \pm 0.23$ & $68.43 \pm 1.36$ & $67.34 \pm 1.66$ \\
\hline Breast percentage & $22.72 \pm 1.42$ & $21.74 \pm 2.41$ & $22.04 \pm 2.71$ \\
\hline Drumstick percentage & $0.85 \pm 0.13$ & $0.81 \pm 0.16$ & $0.68 \pm 0.03$ \\
\hline $\begin{array}{c}\text { Abdomen fat } \\
\text { percentage }\end{array}$ & $8.62 \pm 0.33$ & $9.08 \pm 0.79$ & $9.18 \pm 0.70$ \\
\hline
\end{tabular}

Mean bearing different superscript in column differ significantly $(\mathrm{p} \leq 0.05)$

Table.6 Mean values of Biochemical parameters of broiler chicken

\begin{tabular}{|c|c|c|c|}
\hline Parameters & Treatment 1 & Treatment 2 & Treatment 3 \\
\hline Uric acid mg/dL & $5.38 \pm 0.69$ & $11.28 \pm 2.09$ & $7.7 \pm 2.10$ \\
\hline Creatinine mg/dL & $0.76 \pm 0.05$ & $0.96 \pm 0.21$ & $0.8 \pm 0.1$ \\
\hline Total protein g/dL & $5.2 \pm 0.30$ & $4.82 \pm 0.29$ & $5.7 \pm 0.4$ \\
\hline Albumin g/dL & $1.82 \pm 0.10$ & $1.56 \pm 0.10$ & $1.65 \pm 0.15$ \\
\hline Globulin mg/L & $3.38 \pm 0.37$ & $3.26 \pm 0.28$ & $4.05 \pm 0.25$ \\
\hline ALT IU/L & $5.6 \pm 2.42$ & $5.4 \pm 8.18$ & $5.5 \pm 4.5$ \\
\hline AST IU/L & $350.4 \pm 50.42$ & $484.6 \pm 135.48$ & $472 \pm 238$ \\
\hline Triglycerides mg/dL & $66.1 \pm 21.62$ & $72.08 \pm 14.80$ & $68.95 \pm 13.05$ \\
\hline Total cholesterol mg/dL & $158.8 \pm 15.56$ & $146.4 \pm 19.74$ & $147.5 \pm 50.5$ \\
\hline HDL-Cholesterol mg/dL & $54.26 \pm 7.79$ & $56.6 \pm 10.08$ & $38.4 \pm 3.5$ \\
\hline Glucose mg/dL & $941.44 \pm 115.20$ & $985.86 \pm 145.87$ & $1192.5 \pm 266.5$ \\
\hline
\end{tabular}

Mean bearing different superscript in column differ significantly $(\mathrm{p} \leq 0.05)$

Numerically higher dressing percentage was noticed in $\mathrm{T}_{2}(68.43 \%)$ and $\mathrm{T}_{3}$ group $(67.34 \%)$ compare to $\mathrm{T}_{1}$ group $(66.94 \%)$. Similarly Guerreiro Neto et al., (2011) reported that addition of emulsifier or influence of fat source in the diet did not affect the carcass traits. These results are consistent with Ferreira et al., (2005) reported that supplementing emulsifier in different fat source in the broiler diet did not affect carcass percentage, parts yield and abdominal fat percentage. An et al., (2020) reported that emulsifier supplementation did not affect meat qualities like water content and drip loss among the treatment groups significantly ( $\mathrm{p}>$ $0.05)$. 


\section{Biochemical parameter}

The data on Uric acid $(\mathrm{mg} / \mathrm{dl})$, Creatinine $(\mathrm{mg} / \mathrm{dl})$, Total Protein $(\mathrm{g} / \mathrm{dl})$, Albumin $(\mathrm{g} / \mathrm{dl})$, globulin (mg/dl), ALT (IU/L), AST (IU/L), Triglycerides $(\mathrm{mg} / \mathrm{dl})$, Total cholesterol (mg/dl), HDL Cholestrol (mg/dl) and Glucose $(\mathrm{mg} / \mathrm{dl})$ were presented in Table. 6. The results revealed that no significant difference $(\mathrm{p}<0.05)$ in all the biochemical parameters between treatment groups. Serum concentration of glucose is high in $\mathrm{T}_{3}(1192.5$ $\mathrm{mg} / \mathrm{dl})$ and $\mathrm{T}_{2}(985.86 \mathrm{mg} / \mathrm{dl})$ than $\mathrm{T}_{1}$ group $(941.44 \mathrm{mg} / \mathrm{dl})$ indicated that more of glucose is available in $T_{3}$ and $T_{2}$ group than $T_{1}$ group.

This available glucose was utilized for more growth emulsifier supplemented groups. Serum lipid fractions seemed to be more vulnerable to the effects of supplemental emulsifier. The results of this study agreed with Guerreiro Neto et al., (2011) that total cholesterol, HDL or triglycerides not affected by dietary fat source and emulsifier addition. However, Fascina et al., (2009) observed lower serum triglyceride levels reported in broilers fed soya bean oil supplemented with emulsifier than fed tallow in the diet. Similarly Wang et al., (2016) revealed that increased concentration of total cholesterol and LDL cholesterol in emulsifier treated group than control group. This response in serum biochemical parameters may be related to the type of fat source whether vegetable oil or animal source and their inclusion level and multiple potential mechanisms were involved in the regulation of serum cholesterol (Bontempo et al., 2018).

It is concluded that the inclusion of emulsifier at the rate of $250 \mathrm{~g}$ per metric tonne of feed to the low energy diet that is $80 \mathrm{Kcal}$ lower than the basal diet containing rice bran oil as fat source improved cumulative body weight and feed conversion ratio during market age in broilers. Hence, formulation of low energy diet with inclusion of emulsifier can be formulated to improve the growth performance in broilers.

\section{References}

Aguilar, Y.M., Becerra, J.C., Bertot, R.R., Peláez, J.C., Liu, G. and Hurtado, C.B., 2013. Growth performance, carcass traits and lipid profile of broiler chicks fed with an exogenous emulsifier and increasing levels of energy provided by palm oil. Journal of Food, Agriculture \& Environment, 11(1): 629-633

An, J.S., Yun, W., Lee, J.H., Oh, H.J., Kim, T.H., Cho, E.A., Kim, G.M., Kim, K.H., Lee, S.D. and Cho, J.H. 2020. Effects of exogenous emulsifier supplementation on growth performance, energy digestibility, and meat quality in broilers. Journal of Animal Science and Technology, 62(1): p.43.

Bell D.D. and W.D. Weave 2007. Commercial chicken Meat and Egg Production, $5^{\text {th }}$ Edn, Springer, 2007, reprint xiviii, $1366 \mathrm{p}$

Bontempo,V.,Comi,M., jiang, X.R., Rebucci, R., Caprarulo,V., Giromini, C., Gottardo, D., Fusi, E., Stella,S., Titloni, E., Cattaneo,D and Baladi, a. 2018. Animal Feed science and Technology. 240: 157-164.

Bureau of Indian Standards (2007) Poultry Feeds Specification (Fifth edition) IS 1374: 2007.

Dabbou, S., Schiavone, A., Gai, F., Martinez, S., Madrid, J., Hernandez, F., Martínez Marín, A.L., Soglia, D., Sartore, S., Kalmar, I.D. and Gasco, L. 2019. Effect of dietary globin, a natural emulsifier, on the growth performance and digestive efficiency of broiler chickens. Italian Journal of Animal Science, 18(1) :.530-537.

Fascina, V.B., Carrijo, A.S., Souza, K.M.R., Garcia, A.M.L., Kiefer, C. and Sartori, 
J.R. 2009. Soybean oil and beef tallow in starter broiler diets. Brazilian Journal of Poultry Science, 11(4): 249-256

Ferreira, A.F., Andreotti, M.O., Carrijo, A.S., Souza, K.M.R.,Fascina, V.B and Rodrigues, E.A. 2005.Valor nutricional do oleo de soja, do sebo bovine de suas combinacoes em racoes para frangos de corte. Acta Scientiarum. Animal Science. 27(2): 213-219

Guerreiro Neto, A.C., Pezzato, A.C., Sartori, J.R., Mori, C., Cruz, V.C., Fascina, V.B., Pinheiro, D.F., Madeira, L.A. and Gonçalvez, J.C. 2011. Emulsifier in broiler diets containing different fat sources. Brazilian Journal of Poultry Science, 13(2): 119-125.

Kulkarni, R.C., Dingore, A.D., Durge, S.M., Dinani, O.P. and Amrutkar, S.A. 2019. Supplementation of different emulsifiers on performance of broilers. Journal of Entomology and Zoology Studies. 7(5): 25-29

Maertens L, Leleu S, Rovers M, Segers L,
Delezie E. The addition of a nutritional emulsifier improves broiler performance in an energy diluted diet. In 20th European Symposium on Poultry Nutrition, Prague, Czech Republic, 2015, 44.

Roy, A., Haldar, S., Mondal, S. and Ghosh, T.K. 2010. Effects of supplemental exogenous emulsifier on performance, nutrient metabolism, and serum lipid profile in broiler chickens. Veterinary medicine international, 2010.

Snedecor, G.W. and Cochran, W.G. 1989. Statistical Methods, eight edition. Iowa state University press, Ames, Iowa

Wang, J.P., Zhang, Z.F., Yan, L. and Kim, I.H. 2016. Effects of dietary supplementation of emulsifier and carbohydrase on the growth performance, serum cholesterol and breast meat fatty acids profile of broiler chickens. Animal Science Journal, 87(2): 250-256.

\section{How to cite this article:}

Srinivasan. G., N. Arul Nathan, V. Thanaseelaan, A. Ruba Nanthini and Sunil Chauhan. 2020. Effect of Emulsifier in Low Energy Ration Containing Rice bran oil on Growth Performance of Broiler Chickens. Int.J.Curr.Microbiol.App.Sci. 9(06): 1117-1123. doi: https://doi.org/10.20546/ijcmas.2020.906.138 